\title{
First records of Argonauta spp. collected in the wild and as prey of larger pelagic in the Mexican Central Pacific
}

\begin{abstract}
The first records of the pelagic cephalopod Argonauta nouryi Lorois, 1852 captured alive in shallow waters of the Central Mexican Pacific are presented, complementing such information with a brief analysis of specimens of Argonauta cornuta Linnaeus, 1758 from stomach contents of commercial fish, caught in the sport fishing of said region.
\end{abstract}

Keywords: cephalopods, mollusks, octopods, pelagic, pacific
Volume 2 Issue 4 - 2018

\section{Victor Landa Jaime, Jesus Emilio Michel Morfin, Carlos A Amezcua Gómez, Bernabe Aguilar Palomino, Mirella Saucedo Lozano Departamento de Estudios para el Desarrollo Sustentable de Zonas Costeras, Universidad de Guadalajara-CUCSUR, Mexico}

Correspondence: Jesus Emilio Michel Morfin, Departamento de Estudios para el Desarrollo Sustentable de Zonas Costeras. Universidad de Guadalajara-CUCSUR, Gómez Farías 82, San Patricio-Melaque 48980, Mexico, Email emilio.michel@academicos.udg.mx

Received: May 24, 2018 | Published: July 26, 2018

\section{Introduction}

Pelagic octopuses of the genus Argonauta, whose females secrete a thin and attractive calcareous shell which adhere eggs develop until hatching, are extremely interesting species from the ecological point of view. However, the knowledge generated around their biological habits and especially its vertical-latitudinal migrations and geographical distribution are virtually unknown in rough parts of the world. When in biology there is talk of commercially important species, usually immediately think of large species or considerable wealth, capable of maintaining human demand for food needs, however there are small species that in turn are responsible supports some species trophic links from the point of view anthropic consider important. The presence of these organisms in the Mexican Pacific has been poorly documented and limited information in the literature is referred to trophic entities as part of the food components of large pelagic as sailfish and dolphinfish. ${ }^{1,2}$

\section{Material and methods}

Four specimens were collected on shallow waters of the coast of Jalisco. The organisms were collected by hand and keep on salt water until his revision on facilities of University of Guadalajara, site in Melaque, Jal., Mexico. After check his taxonomic identity the Argonauta nouryi specimens are preserved on alcohol 70\%.

\section{Results}

In this paper disclosed the earliest records of small pelagic mollusk Argonauta nouryi on the Bahía de Navidad, coast of Jalisco, Mexico, in March of $2017\left(19^{\circ} 12^{\prime} 10^{\prime \prime} \mathrm{N} ; 1^{\circ} 4^{\circ} 44^{\prime} 6.8^{\prime \prime} \mathrm{W}\right.$ (Figure 1) (Figure 2) (Figure 3 ) and A. cornuta, which although not come to form large biomasses, if they represent an important pelagic fish feeding large percentage, which represent great importance in commercial fisheries and sport fishing.

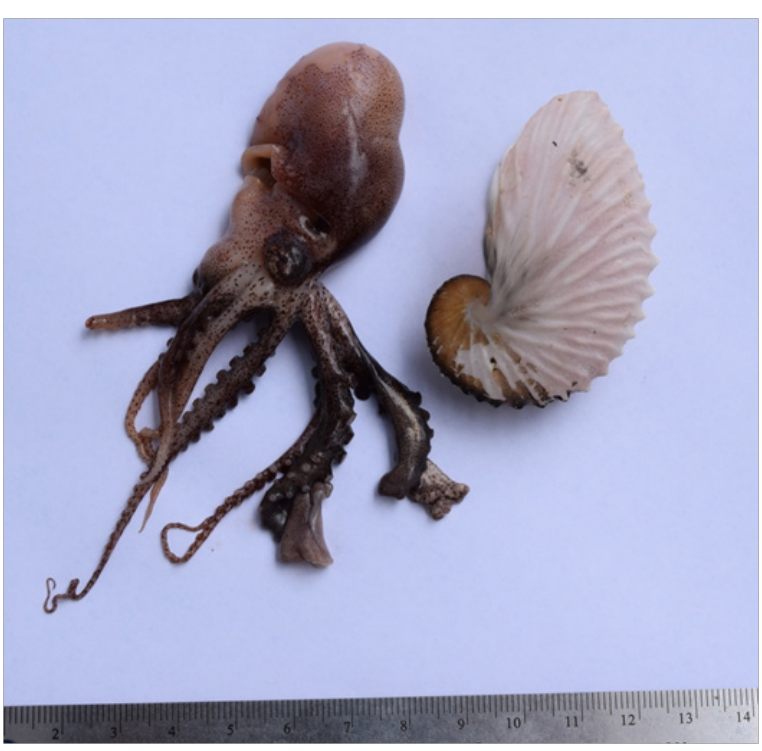

Figure I Argonauta nouryi collected alive in the shallow waters of the coast of Jalisco, Mexico. Shell and soft body (Photo by E. Michel).

The presence of these organisms in the region has been poorly documented and limited information in the literature is referred to trophic entities as part of the food components of large pelagic as sailfish, dolphinfish and merlin among others, where specimens are already in an advanced state of digestion or there are only fragments of shells or peaks, disregarding the origin thereof being great swimmers these dams; however this time are also presented records of four living organisms caught in the free state in shallow waters off the coast of Jalisco, reflecting on the one hand, a weak effort by research initiatives around the scarce knowledge of this type of organisms. In this paper, in addition to spreading the finding in this coastal Pacific 
region also it shows the number and percentages of other individuals analyzed stomach contents of fish and the need to extend this line of research as an integral part highlights knowledge of coastal resources of Mexican seas. Reviewing the results based by analyzing stomach contents of 310 sailfish and 319 dolphinfish (Figure 4), captured during fishing tournaments in Manzanillo, Colima; Barra de Navidad and Puerto Vallarta, Jalisco, Mexico in 2002, 2003 and 2004, found

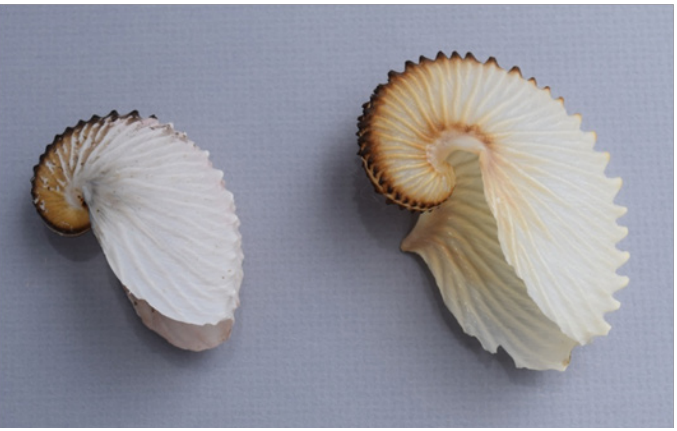

Figure 2 Lateral view of shell of Argonauta nouryi (left) and A. cornutta (right). (Photo by E. Michel).

\section{Dolphinfish}

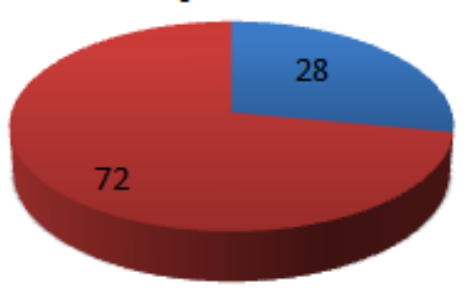

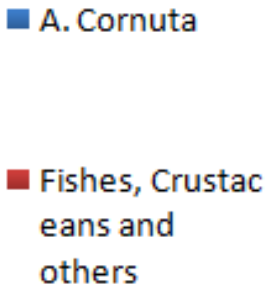

that sailfish are mainly fed on cephalopods and fish, whose major dams according to the IIR were: Argonauta cornuta reaching 39\% of total food components (86 dams); while the dolphinfish was fed three main groups (fish, crustaceans and cephalopods), where also the species represented the highest percentage was Argonauta cornuta $28 \%$ of total analyzed dams (77).

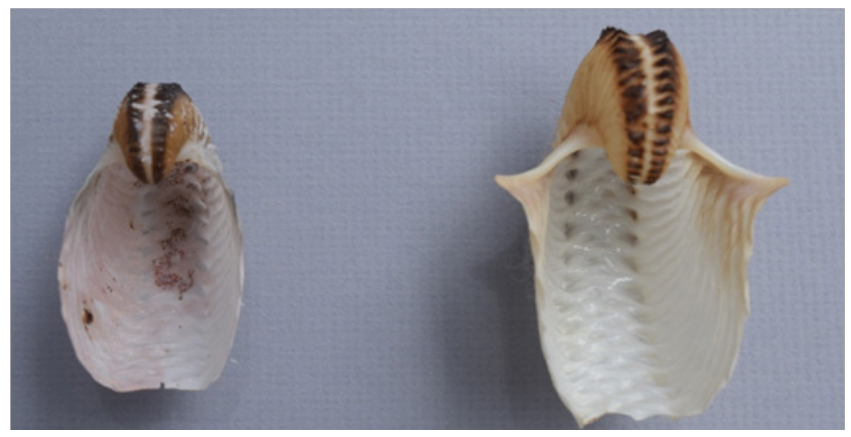

Figure 3 Ventral view of shell of Argonauta nouryi (left) and A. cornutta (right). (Photo by E. Michel).

\section{Sailfish}

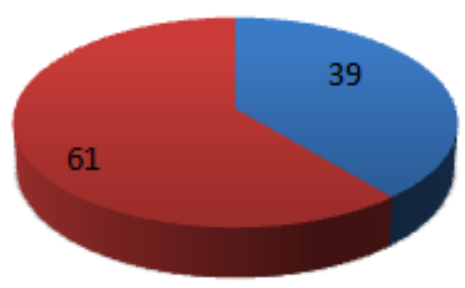

A. Cornuta

Fishes, Crustac
eans and
others

Figure 4 Percentage of Argonauta cornuta on stomach contents from Istiophorus platypterus sailfish and Coryphaena hippurus dolphinfish.

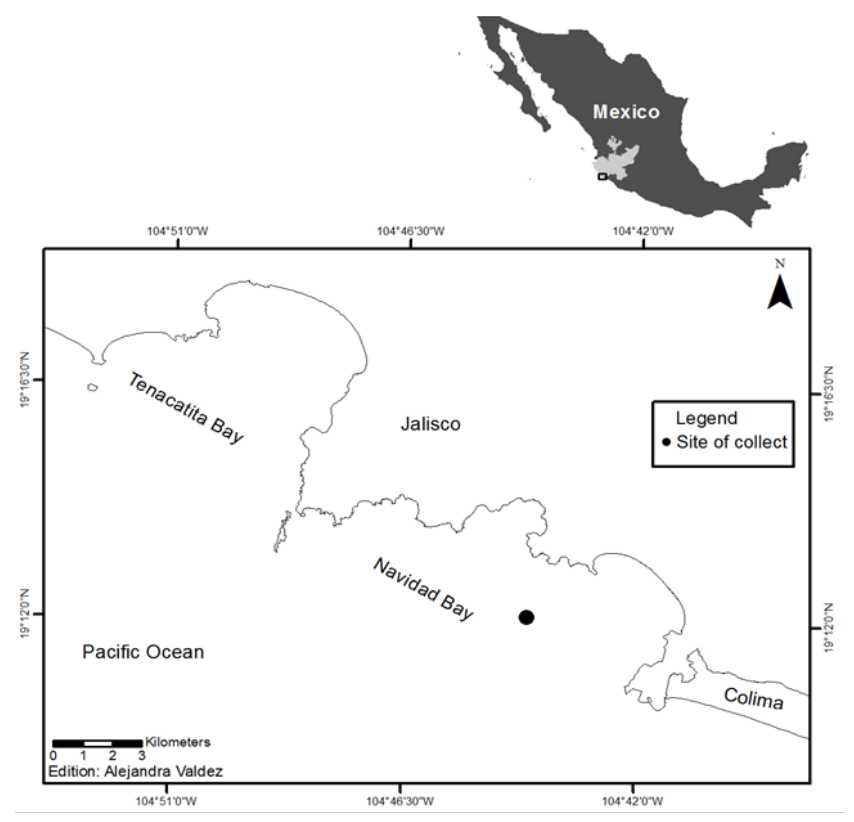

Figure 5 Collect area to Argonauta nouryi, shallow waters of the coast of Jalisco, Mexico.
In addition, four agencies Argonauta nouryi were collected in areas near the coast of Jalisco, in March 2017 (Figure 5). Such organisms were accidentally found in the surface layer of the sea swimming freely. While it is known that these mollusks are usually carried by currents from the open sea to the beaches, ${ }^{3}$ this fact is rarely observed because they usually have vertical migrations in the water column and way to collect them alive is through trawls midwater, however, generally can make a great effort sampling without satisfactory results.

\section{Discussion}

This report constitute an important finding, because these organisms although spread over large geographic regions are considered as citizens of open water at a considerable distance from the coast so its presence in this region of the Pacific Tropical Mexican, ${ }^{4}$ had not been previously documented in free-living conditions in the area described in this study. It is noteworthy that the four specimens were collected in the same week, during a strong winds event in the region.

Also, recent studies have also documented that Argonauts, when they are occasionally carried by the currents towards the coast, are not only a favorite prey of big fish but also some birds too, as the common black hawk Buteogallus anthracinus. ${ }^{5}$ Therefore, it is considered that knowledge about the role of Argonaut mollusks in the marine trophic dynamics is still incipient. 


\section{Acknowledgments}

The authors' thanks Gerardo and Daniel Kosonoy for the donation of a specimen of A. nouryi. Alejandra Valdez for the preparation of the map.

\section{Conflict of interests}

Author declares that there is no conflict of interest.

\section{References}

1. Aguilar Palomino B, Galván-Magaña F, Abitia-Cárdenas LA, et al. Aspectos alimentarios del dorado Coryphaena hippurus linnaeus, 1758 en Cabo San Lucas, Baja California Sur, México. Ciencias Marinas. 1998;24(3):253-265.
2. Amezcua-Gomez CA. Relaciones troficas entre el Pez Vela (Istiophorus platypterus) y el Dorado (Coryphaena hippurus) en la costa de los estados de Jalisco y Colima, México. Tesis de maestría. Instituto Politécnico Nacional (IPN) CICIMAR; 2009.

3. Hochberg FG, Camacho-García YE. Squids and octopuses. In: Wehrtmann IS, Cortés J, editors. Marine biodiversity of Costa Rica, Central America. Springer; 2009. p. 399-408.

4. Allcock L. Argonauta nouryi. The IUCN Red List of Threatened Species. 2014:e.T163083A970914.

5. Herrera F, Gonzalez M. First record of predation of the paper nautilus Argonauta nouryi (Cephalopoda: Argonautidae) by the Common Black Hawk Buteogallus anthracinus (Accipitriformes: Accipitridae). Revista de Ciencias Marinas y Costeras. 2017;9(1):9-15. 